\title{
REPERTORIO BIBLIOGRAFICO \\ SOBRE JUSTICIA Y TRIBUNALES
}

POR

JOSE JUAN TOHARIA

Catedrático de Sociología

Universidad Autónoma de Madrid

La bibliografía que aquí se ofrece constituye un primer intento - orientativo y selectivo, por tanto, más que exhaustivo- de recopilar los estudios disponibles referidos al tema de justicia y tribunales. Se trata por otra parte de una bibliografía centrada exclusivamente en trabajos realizados no desde una óptica estricta y específicamente jurídica, sino desde la perspectiva de las ciencias sociales (sociología y ciencia política, fundamentalmente).

Los textos aquí recogidos aparecen agrupados en cuatro grandes epígrafes: 1. Obras de carácter general (estudios generales, personal judicial, organización y estructura de tribunales, etc.).-2. Estudios antropológicos y comparativos. Obras referidas a países concretos desde una perspectiva comparada.-3. Estudios sobre la toma de decisiones judiciales.-4. Estudios sobre justicia y política.

Las obras se citan por la fecha de su edición original. Cuando ésta se encuentra agotada, se indica la fecha de la edición posterior utilizada, indicando entre paréntesis y tras las siglas e. o. (= edición original) la fecha de la primera edición.

En cuanto a las revistas, las abreviaturas usadas son las siguientes:

A. J. C. L. = American Journal of Comparative Law.

A. J. S. = American Journal of Sociology.

A. P.S. R. = American Political Science Review.

J. A. Jud. Soc. = Journal of the American Judicature Society.

J. C. R. = Journal of Conflict Resolution.

L. S. R. = Law and Society Review.

P. Sc. Q. = Political Science Quarterly.

R. D. J. = Revista de Derecho Judicial.

U. Penn. L. R. = University of Pennsylvania Law Review.

W. L. R. = Wisconsisn Law Review.

\section{OBRAS DE CARACTER GENERAL}

Adamany, David W.:

1965 Judicial misconduct, «J. A. Jud. Soc.», 48, febrero, 163-195.

1967 Selected readings on the Administration of Justice and Its Improvement (Chicago, American Judicature Society). 
American Judicature Societr:

1970 Judicial Selection and Tenure (Chicago, American Judicature Society). Arnaud, J::

1976 La Justice (París).

AUBERT, Vilhelm:

1963 Competition and Dissensus: Two Types of Conflict Resolution, BECEÑA, F.: «J. C. R.», vol. 7, núm. 26.

1928 Magistratura y Justicia (Madrid).

Bоввіо, Norberto:

1974 Quale giustizia, quale legge, quale giudice, en Pizzorusso, ed. (1974).

BORKIN, Joseph:

1962 The Corrupt Judge.

BRAITHWAITE, W.:

1971 Who Judges the Judge: A Study of Procedures for Removal and Retirement (Chicago, American Bar Foundation).

Cardozo, Benjamin N.:

1960 (e.o. 1921) The Nature of the Judicial Process (New Haven, Yale University Press).

Carretero Pérez, Adolfo:

1964 Introducción a la organización judicial, «R. D. J.», núm. 19, julio-septiembre, págs. 121-128.

1964 La organización de la Administración de Justicia en 1808, «R. D. J.», número 20, octubre-diciembre, págs. 145-156.

1965 La Administración de Justicia de 1808 a 1835, «R. D. J.», núm. 21, enero-matzo, págs. 159-172.

1965 La Administración de Justicia de 1835 a 1868 (primera parte), «R. D. J.», número. 22, abril-junio, págs. 117-128.

1965 La Administración de Justicia de 1835 a 1868 (segunda parte), «R. D. J.», número 24, octubre-diciembre, págs. 121-127.

1966 La Administración de Justicia de 1868 a 1898 (primera parte), «R. D. J.», número 25, enero-marzo, págs. 83-97.

1966 La Administración de Justicia de 1868 a 1898 (segunda parte), «R. D. J.», número 26, abril-junio, págs. 129-144.

1966 La Administración de Justicia de 1868 a 1898 (tercera parte), «R. D. J.», número 27 , julio-septiembre, págs. 120-136.

1966 La Administración de Justicia de 1868 a 1898 (cuarta parte), «R. D. J.», número 28 , octubre-diciembre, págs. 47-58.

1968 El poder judicial de 1868 a 1898, «R.D. J.», núm. 34, abril-junio, páginas 89-101.

\section{Casamayor:}

1956 Les juges (París, Du Seuil).

Comisión General de Codificación:

1970 Crónica de la codificación española. I: La organización judicial (Madrid, Ministerio de Justicia).

CORWIN, Edward S.:

1914 The Doctrine of Judicial Review: Its Legal and Historical Basis, and Other Essays (Princeton, N. J., Princeton University Press).

1934 The Twilight of the Supreme Court: A History of Our Constitutional Theory (New Haven, Yaye University Press). 
CHASE, H.:

1972 Federal Judges: The Appointing Process (Minneapolis, University of Minnesota Press).

DAHL, R. Y BOLDEN, C.:

1968 The American Judge.-A Bibliography (Vienna, Virginia. Coiner).

Danelski, David J.:

1965 A Supreme Court Justice is Appointed (Nueva York, Random House).

Dawson, John P.:

1960 A History of Lay Judges (Cambridge, Mass., Harvard University Press).

1968 The Oracles of the Law.

Di Federico, Giuseppe:

1968 La Giustizia come organizzazione. Il reclutamento dei Magistrati (Bari, Laterza).

EскноF, Thorstein:

1966 The Mediator, the Judge and the Administrator in Conflict Resolution, en B.-M. Blegvad (ed.), Contributions to the Sociology of Law.

Elliotr, Sheldon D.:

1959 Improving our Courts: Collected Studies on Judicial Administration (Dobbs Ferry, N. Y., Oceana).

Ewing, C. A. M.:

1938 The Judges of the Supreme Court, 1789-1937 (Minneapolis, University of Minnesota Press).

Fairman, Charles:

1939 Mr. Justice Miller and the Supreme Court: 1862-1890 (Cambridge, Mass., Harvard University Press).

Frank, Jerome:

1949 (e. o. 1930) Law and the Modern Mind (Nueva York, Coward).

1949 Courts on Trial (Princeton, N. J., Princeton University Press).

Frankfurter, Felix, y Landis, James M.:

1927 The Business of the Supreme Court: A Study in the Federal Judicial System (Nueva York, Macmillan).

FrankfurTer, Felix:

1957 The Supreme Court in the Mirror of Justices, «Univ. of Penn. L. R.», 105 (abril): 781-796.

Gallego Anabitarte, R.:

1971 Administración y jueces: gubernativo y contencioso (Madrid, Instituto de Estudios Administrativos).

Giannini, Mirella:

1978 Giustizia e Mezzogiorno (Venecia, Marsilio Editor).

Glick, Henry R., y VINES, Kenneth M.:

1973 State Court Systems.

Grossman, J., y Tanenhaus, J. (eds):

1969 Frontiers of Judicial Research (Nueva York, Wiley).

Gutiérrez, Carlos José:

1979 El funcionamiento del sistema jurídico (San José de Costa Rica, Ed. Juricentro).

Haines, Charles G.:

1959 (e.o. 1914) The American Doctrine of Judicial Supremacy (Nueva York, Russell).

Haynes, Evan:

1944 The Selection and Tenure of Judges (Newark, N. J., National Conference of Judicial Councils). 
Herndon, J.:

1962 Appointment as a means of initial accession to elective state Courts of last resort, «North Dakota L. R.», 38 (enero): 60-73.

Holmes, Oliver W.:

1963 (e. o. 1881) The Common Law (Cambridge, Mass., Harvard University Press).

ЈАСOB, H.:

1964 The effect of institutional differences in the recruitment process: the case if State hedges, «Journal of Public Law», 13 (1), págs. 104-119.

Jaros, Dean, y MENDELSOHN, R. I.:

1967 The Judicial Role and Sentencing Behavior, «Midwestern Journal of Political Science», 11.

KLEIN, Fannie J.:

1963 Judicial Administration and the Legal Profession (Dobbs Ferry, N. Y., Oceana):

LEONARDI, F.:

1968 Il cittadino e la giustizia (Padova).

MASON, A. T.:

1962 The Supreme Court: Palladium of Freedom (Ann Arbor, Mich., University of Michigan Press).

1965 William Howard Taft: Chief Justice (New York, Simon and Schuster).

MiLlar, Robert W.:

1952 Civil Procedure of the Trial Court in Historical Perspective (New York University, Law Center).

Moriondo, E.:

1967 L'ideologia della magistratura italiana (Bari, Laterza).

Mott, Rodney L.; Albright, S. P., y Semmerling, H. R.:

1933 Judicial Personnel («Anals, American Academy of Political and Social Science», 167, págs. 143-155).

MotT, Rodney L.:

1948 The Measurement of Judicial Personnel, «New York University Law Quarterly Review», 23: 262-277.

Murphy, Walter F.:

1964 Elements of Judicial Strategy (University of Chicago Press).

NAGEL, S.:

1970 Characteristics of Supreme Court Greatness, «American Bar Association Journal», 56 (octubre): 957-959.

1963 Off-the-bench judicial attitudes, en Schubert, ed. (1963): 29-54.

1973 Comparing Elected and Appointed Judicial Systems (Sage Professional Paper in American Politics 04-001; Beverly Hills and London, Sage Publications).

OTTE, George:

1972 Role Theory and the Judicial Process: A Critical Analysis, «St, Louis University Law Journal», 16.

Pagani, Angelo:

1968 Gli attegiamenti sociali dei giudici (Varese, Centro Nacional de Prevención y Defensa Social).

1969 La professione del Giudice (Varese, Instituto Editorial Cisalpino).

1972 Profilo ideologico del giudice, «Quaderni di Sociologia», XXI.

Pizzorusso, A. (ed.):

1974 L'ordinamento giudiziario (Bolonia, Mulino). 
Plaza Navarro, Manuel de la:

1957 La Magistratura y sus bombres (Madrid, Góngora).

Pound, Roscoe:

1963 (e. o. 1906) The Causes of Popular Dissatisfaction with the Administration of Justice (Chicago, American Judicature Society to Promote the Efficient Administration of Justice).

1940 Organization of Courts (Boston, Little).

RAYNAL, Jean:

1964 Histoire des institutions judiciaires (París, A. Colin).

Ríos SaRmiento, A.:

1956 Memorias de un juez español (Madrid, Juventud).

ROUSSELET, M.:

1960 Histoire de la Justice (París, P. U. F.).

Rull Villar, B.:

1959 Memorias de un juez español (Madrid, Aguilar).

SAIZ GÓMEZ, M.:

1921 Memorias de un magistrado jubilado (Madrid, Reus).

SCHMidHauser, John R.:

1960 The Supreme Court: Its Politics, Personalities and Procedures (New York, Holt).

Schubert, Glendon:

1957 The Presidency in the Courts (Minneapolis, University of Minnesota Press).

SChWARTZ, R. D., y Miller, J. C.:

1964 Legal Evolution and Societal Complexity, «A. J. S.», 70.

Scigliano, R.:

1962 The Courts. A Reader in the Judicial Process (Boston, Little Brown).

Senese, Ferrajoli, Accattatis y Scarpari:

1978 Política y justicia en el Estado capitalista (Barcelona, Fontanella).

SLESSER, Henry H.:

1962 The Art of Judgment and Other Studies (Londres, Stevens).

SMITH, S.:

1970 Bibliograpby: Judges. Appointment and Removal. Selected Writings (New Haven, Yale Law Library).

TAPP, June L. y KoHLberg, Lawrence:

1971 Developing Sense of Law and Legal Justice, «Journal of Social Issues», volumen 27 , núm. 2.

Thurstone, Louis L., y Degan, J. W.:

1951 A Factorial Study of the Supreme Court, «Proceedings, National Academy of Sciences», 37: 628-635.

Toharia, José Juan:

1974 Modernización, autoritarismo y Administración de Justicia en España (Madrid, Cuadernos para el Diálogo).

1974 Cambio social y vida jurídica en España (Madrid, Cuadernos para el Diálogo):

1974 Economic Development and Litigation: The Case of Contemporary Spain, en L. M. Friedman y M. Rehbinder, eds., The Sociology of Judicial Proceedings (Bielefeld, Zentrum fur Interdisziplinare Forschung).

1975 El juez español. Un análisis sociológico (Madrid, Tecnos).

Treves, Renato:

1974 El juez y la sociedad (Madrid, Edicusa). 
VANDERBILT, Arthur T.:

1949 Minimum Standards of Judicial Administration (New York University, Law Center).

Vega Benayas, Carlos de la:

1961 Moral, estilo y función judicial (primera parte), «R.D. J.», núm. 5, enero-marzo, págs. 131-176.

1961 Moral, estilo y función judicial (segunda parte), «R.D. J.», núm. 6, abril-junio, págs. 90-135.

WARREN, George:

1942 Traffic Courts (Boston, Little).

WiLLoughBY, William F.:

1929 Principles of Judicial Administration (Washington, Brookings Institution).

Winters, G., y Allard, B.:

1964 Two dozen misconceptions about judicial selection and tenure, "Journal of the American Judicature Society», 48, diciembre, págs. 138-144.

Zeisel, Hans, Kalven, Harry, y Buccholz, Bernard:

1959 Delay in the Court (Boston, Little).

\section{ESTUDIOS ANTROPOLOGICOS Y COMPARATIVOS. OBRAS REFERIDAS A PAISES CONCRETOS DESDE UNA PERSPECTIVA COMPARATIVA}

Abraham, Henry J.:

1962 The Judicial Process: An Introductory Analysis of the Courts of the United States, England and France (New York, Oxford University Press).

Berman, Harold J.:

1963 Justice in the USSR: An Interpretation of Soviet Law (Cambridge, Mass., Harvard University Press).

Bohannan, Paul:

1957 Justice and Judgment Among the Tiv (Oxford University Press).

BusEY, James L.:

1964 Latin America: Political Institutions and Processes (New York, Random House).

CAPPellettri, Mauro:

1971 Judicial Review in the Contemporary World.

CoHN, Haim H. (ed.):

1971 Jewish Law in Ancient and Modern Israel.

COLE, Taylor:

1959 Three Constitutional Courts: A Comparison, «A. P. S. R.», 53: 963-984.

DAHRENDORF, Ralf:

1966 Los jueces alemanes, en Sociedad y libertad (Madrid, Tecnos).

DaNelski, David J.:

1967 Conflict and Its Resolution in the Supreme Court, «J.C. R.», 11.

EPSTEIN, Arnold:

1954 Juridical Tecbniques and the Judicial Process: A Study in African Customary Law (Rhodes-Livingstone Papers, núm. 23, Manchester University Press).

FERRARESE, M. R.:

1979 Un sindacato di giudici in Francia, en Sociologia del Diritto, VI, páginas 83-119. 
FRANK, Jerome:

1961 Marble Palace: The Supreme Court in American Life (Nueva York, Knopf).

Gluckman, Max:

1967 (e.o. 1955) The Judicial Process Among the Barotse of Northern Rbodesia (Manchester University Press).

1965 The Ideas in Barotse Jurisprudence (New Haven, Yale Univ. Press).

1965 Politics, Law and Ritual in Tribal Society (Chicago, Aldine).

GoDECHOT, Jacques:

1968 Les Institutions de la France sous la Révolution et l'Empire.

GoldMAN, S.:

1971 American Judges: their selection, tenure, variety and quality, "Current History», 61 (julio): 1-8.

1967 Judicial Appointments to the United States Courts of Appeals, «W. L. R.» (invierno): 186-214.

Grant, J. A. C.:

1954 Judicial Control of Legislation: A Comparative Study, «American Journal of Comparative Law», 3: 186-198.

Grossman, Joel B.:

1965 Lawyers and Judges. The $A B A$ and the Politics of Judicial Selection (Nueva York, John Wiley).

Grossman, J. B., y Grossman, M. H. (eds.):

1971 Law and Change in Modern America.

Hahm, Pyong-Choon:

1969 The Decision Process in Korea, en Schubert y Danelski, eds. (1969).

HAMER, John H.:

1972 Dispute Settlement and Sanctity: An Ethiopian Example, «Anthropological Quarterly», 45.

Hayakawa, Takeo:

1964 Civil Liberties in the Japanese Supreme Court, en Schubert, ed. (1964).

HaZARD, John N., y SHAPIRo, Isaac:

1962 The Soviet Legal System: Post-Stalin Documentation and Historical Commentary (Dobbs Ferry, N. Y., Oceana).

JACKSON, Richard:

1940 The Macbinery of Justice in England (Cambridge University Press).

JACOB, Herbert:

1965 Justice in America (Boston, Little).

1966 Judicial insulation- electiones, direct participation and public attention to the Courts in Wisconsin, «W. L. R.» (verano): 801-819.

Kalven, H., y Zeisel, H.:

1966 The American Jury.

KARLEN, Delmar:

1963 Appellate Courts in the United States and Englad (New York University Press).

KING, Jerome B.:

1965 Constitutionalism and the Judiciary in France, «P. Sc. Q.», 80: 62-87.

KUPER, H., y KUPER, L. (eds.):

1965 African Law: Adaptation and Development.

LAdinsky, J., y Silver, A.:

1967 Popular Democracy and Judicial Independence: Electorate and Elite Reactions to Two Wisconsin Supreme Court Electiones, «W. L. R.» (invierno): 128-169. 
LEv, Daniel S.:

1972 Islamic Courts in Indonesia.

Llewellyn, Karl N., y Hoebel, E. A.:

1941 The Cheyenne Way: Conflict and Case Law in Primitive Jurisprudence (Norman, Univ. of Oklahoma Press).

MCWHINNEY, Edward:

1960 (e. o. 1956) Judicial Review in the English-Speaking World (University of Toronto Press).

1962 Constitutionalism in Germany and the Federal Constitutional Court (Leiden, Sythoff).

Mayers, Lewis:

1964 (e. o. 1955) The American Legal System: The Administration of Justice in the United States by Judicial, Administrative, Mi-

MeHren, Arthur von: litary and Arbitral Tribunals (Nueva York, Harper).

1956 The Judicial Process: A Comparative Analysis, «American Journal of Comparative Law», 5: 197-228.

Merryman, John H., y Vigoriti, V.:

1967 When Courts Collide: Constitution and Cassation in Italy, «A. J. C. L.», número 15.

МоECH, G.:

1970 La giustizia in Italia (Milano).

NADER, Laura:

1964 An Analysis of Zapotec Law Cases, «Ethnology», 3.

Nathanson, Nathaniel L.:

1958 Constitutional Adjudication in Japan, «A. J. C. L.», 7: 195-218.

RUBINSTEIN, Amnon:

1971 Law and Religion in Israel, en Cohn, ed. (1971).

Rupp, Hans G.:

1960 Judicial Review in the Federal Republic of Germany, «A. J. C. L.», 9: $29-47$.

Salacuse, Jeswald:

1969 An Introduction to Law in French-Speaking Africa.

Schlegel, Stuart A.:

1970 Tiruray Justice.

SCHMIDHAUSER, J.:

1960 The Supreme Court. Its Politics, personalities and procedures (New York, Holt Rinehart and Winston).

Schubert, G., y Danelski, D. (eds.):

1969 Comparative Judicial Behavior.

SCHWARTZ, Richard D.:

1954 Social Factors in the Development of Legal Control: A Case Study of two Israeli Settlements, «Yale Law Journal», 63.

Sollie, Finn:

1958 Courts and Constitutions: A Comparative Study of Judicial Review in Norway and the United States, tesis doctoral, Johns Hopkins University.

Stevens, Charles R.:

1971 Modern Japanese Law as an Instrument of Comparison, «A. J. C. L.», 19. TORGERSON, Ulf:

1963 The Role of the Supreme Court in the Norwegian Political System, en G. Schubert, ed. (1963). 
VANSINA, Jan:

1965 A Traditional Legal System: The Kuba, en Kuper y Kuper, eds. (1965).

VINES, $\mathrm{K}$ :

1969 The Judicial Role in the American States, en Grossman y Tanenhaus, editores (1969): $461-485$.

1964 Federal District Judges and Race Relationes Cases in the South, «Journal of Politics», 26.

Wenner, Manfred W.; Wenner, Lettie M., y Flango, V. E.:

1978 Austrian and Swiss Judges: A Comparative Study, «Comparative Politics», vol. 10, núm. 4, págs. 499-517.

\section{ESTUdIOS SOBRE LA TOMA DE DECISIONES JUdICIALES}

AdAMANY, D.:

1969 The party variable in judge's voting: conceptual notes and a case study, «A.P. S. R.», 6, marzo, págs. 57-73.

Atkinson, D. N., y Neuman, D. A.:

1970 Judicial Attitudes and Defendant Attributes: Some Consequences for Municipal Court Decision-Making, «Journal of Public Law», 19.

BAADE, Hans W. (ed.):

1964 Jurimetrics (Nueva York, Basic Books).

BECKER, Theodore L.:

1966 Political Behavioralism and Modern Jurisprudence: A Working Theory and Study in Judicial Decision-Making (Chicago, Rand McNally).

Bernard, Jessie:

1955 Dimensions and Axes of Supreme Court Decisions: A Study in the Sociology of Conflict, «Social Forces», 34: 19-27.

Canon, B.:

1972 The Impact of Rormal Selection Processes on the Characteristics of Judges -Reconsidered, «L.S. R.», 6 (mayo), págs. 579-594.

DANelski, David J.:

1966 Values as Variables in Judicial Decision-Making: Notes Toward a Theory, «Vanderbilt Law Review», vol. 19.

DAYNARD, R. A.:

1971 The Use of Social Policy in Judicial Decision-Making, "Cornell Law Review», vol. 56.

FAIR, Daryl R.:

1967 An Experimental Application of Scalogram Analysis to State Supreme Court Decisiones, «W. L. R.», págs. 449 y sigs.

Feelex, M.:

1969 Comparative analysis of decision-making on State Supreme Courts, tesis doctoral, Universidad de Minnesota.

1971 Another Look at the «Party Variable» in judicial decision-making. An analysis of the Michigan Supreme Court, «Polity», 4 (otoño): 91-104.

GAUDET, Frederick J.:

1938 Individual Differences in the Sentencing Tendencies of Judges, "Archives of Psychology», 32, núm. 230.

GOLDMAN, S.:

1966 Voting Bebavior on the United States Courts of Appeals, 1961-1964, «A.P.S. R.», 60 (junio): 374-383. 
Grossman, Joel B.:

1966 Social Backgrounds and Judicial Decision-Making, «Harvard Law Review», 1.551.

Grunbaum, Werner F., y Newhouse, Albert:

1965 Quantitative Analysis of Judicial Decisions: Some Problems in Prediction, «Houston Law Review», 3: 201-220.

Haines, Charles G.:

1922 General Observations on the Effects of Personal, Political and Economic Influences in the Decisions of Judges, «Illinois Law Review», 17: 96-116.

LASSWELl, Harold D.:

1930 Self-Analysis and Judicial Thinking, «International Journal of Ethics», 40: 354-362.

LEE, F.:

1971 Judicial Selection: An Explanatory Variable of Judicial Bebavior on Bipartisan State Supreme Courts, tesis doctoral, Filadelfia, Universidad de Pennsylvania.

LOEB, Louis S.:

1965 Judicial Blocs and Judicial Values in Civil Liberties Cases Decided by the Supreme Court and the United States Court of Appeals for the District of Columbia Circuit, «American University Law Review», 14: 146-177.

MetzleR, L.:

1965 Characteristics of federal judges preferred by the American Bar Association, tesis doctoral, Urbana: Universidad de Illinois.

MurpHy, Walter F.:

1964 Elements of Judicial Strategy (University of Chicago Press).

NAGEL, Stuart S.:

1961 Political Party Affiliation and Judges decisiones, «A.P.S.R.», 55: 843-850.

1961 Unequal party representation on the State Supreme Courts, en «J. A. Jud. Soc.», 45 (agosto): 62-65.

1962 Etbnic Affiliations and Judicial Propensities, «Journal of Politics», 24: 92-110.

1962 Judicial backgrounds and criminal cases, «Journal of Criminal Law Criminology and Police Science», 53 (septiembre): 333-339.

1962 Testing Relations Between Judicial Characteristics and Judicial DecisionMaking, «Western Political Quarterly», 15: 425-437.

1965 Predicting Court Cases Quantitatively, «Michigan Law Review», 63: 1411-1422.

Peltason, Jack W.:

1961 Fifty-eight Lonely Men: Soutbern Federal Judges and Scbool Desegregation (New York, Harcourt).

SCHMIDHAUSER, John R.:

1959 The Justices of the Supreme Court: A Collective Portrait, «Midwest Journal of Political Science», 3: 1-57.

1962 Stare Decisis, Dissent and the Background of the Justices of the Supreme Court of the United States, «University of Toronto Law Journal», 14: 194-212.

SCHROEDER, Theodore:

1918 The Psychologic Study of Judicial Opinions, "California Law Review», 6: 89-113. 
SCHUBERT, Glendon:

1959 Quantitative Analysis of Judicial Bebavior (Glencoe, Ill., Free Press).

1960 Constitutional Politics: The Political Bebavior of Supreme Court Justices and the Constitutional Policies That They Make (New York Holt).

1962 The 1960 Term of the Supreme Court: A Psychological Analysis, «A. P. S. R.», 56: 90-107.

1962 A Solution to the Indeterminate Factorial Resolution of Thurstone and Degan's Study of the Supreme Court, «Behavioral Science», 7: 448-458.

1963 Judicial Attitudes and Voting Bebavior: The 1961 Term of the United States Supreme Court, «Law and Contemporary Problems», 28: 100-142.

1963 Bebavioral Research in Public Law, «A.P.S. R.», 57: 433-445.

1965 The Judicial Mind: The Attitudes and Ideologies of Supreme Court Justices, 1946-1963 (Evanston, Ill., Northwestern Univ. Press).

1965 Jackson's Judicial Philosophy: An Exploration in Value Analysis, «A.P.S.R.», 59: 940-963.

SCHUBERT, Glendon (ed.):

1963 Judicial Decision-Making (New York, Free Press).

1964 Judicial Bebavior: A Reader in Theory and Research (Chicago, Rand McNally).

SHAPIRO, Martin:

1964 Stability and Change in Judicial Decision-Making: Incrementalism or Stare Decisis?, «Law in Transition Quarterly», 2: 134 y sigs.

SNYDER, Eloise:

1958 The Supreme Court as a Small Group, «Social Forces», 36: 232-238.

Somrt, Albert; Tanenhaus, Joseph, y WiLKE, Walter:

1960 Aspects of Judicial Sentencing Bebavior, «University of Pittsburg Law Review», 21: 613-620.

Sprague, John D.:

1968 Voting Patterns of the United States Supreme Court.

Tanenhaus, Joseph:

1966 The Cumulative Scaling of Judicial Decisions, «Harvard Law Review», 79: 1583 y sigs.

ThibaUt, John; WaLKER, Laurens, y Lind, E. A.:

1972 Adversary presentation and bias in Legal Decision-Making, «Harvard Law Review», 86: 386 y sigs.

Ulmer, S. Sidney:

1960 The analysis of bebavior patterns of the United States Supreme Court, «Journal of Politics», 22: 629-653.

1960 Supreme Court Bebavior and Civil Rights, «Western Political Quarterly», 13: 288-311.

1962 The political party variable in the Michigan Supreme Court, «Journal of Public Law», 11 (Spring): 352-362.

1965 Toward a Theory of Sub-Group Formation in the United States Supreme Court, «Journal of Politics», 27: 133-152.

1970 Dissent behavior and the social background of Supreme Court Justices, «Journal of Politics», 32 (agosto): 580-598.

1973 Social background as an indicator to the votes of the Supreme Court justices in criminal cases, «Midwest Journal of Political Science», 17 (agosto).

WALKER, Thomas G.:

1972 A note concerning partisan influences on trial-judge decision making, «L. S. R.», 6 (mayo): 645-650. 
Wassesrstrom, Richard A.:

1961 The Judicial Decision. Toward a Theory of Legal Justification.

\section{ESTUDIOS SOBRE JUSTICIA Y POLITICA}

ANDRÉS IBÁÑEZ, Perfecto:

1976 Para una práctica judicial alternativa, «Anales de la cátedra Francisco Suárez», núm. 16 (Granada).

Barcellona, P.:

1973 L'uso alternativo del diritto (Bari, Laterza).

BECKER, Theodore L.:

1970 Comparative Judicial Politics. The Political Functioning of Courts.

BECKER, Theodore L. (ed):

1969 The impact of Supreme Court Decisions.

BERMAN, Jesse:

1969 The Cuban Popular Tribunals, "Columbia Law Review», 69: 1317 y sigs.

Bickel, Alexander M.:

1965 Politics and the Warren Court.

BLACK, Charles L.:

1960 The People and the Court: Judicial Review in a Democracy (New York, Macmillan).

Corwin, Edward S.:

1957 (e. o. 1938) Court over Constitution: A Study of Judicial Review as an Instrument of Popular Government (Gloucester, Mass., Smith).

Cuadernos para el Dí́logo:

1969 Justicia y política (número extraordinario XVII, diciembre).

DAHL, Robert A.:

1957 Decision-Making in a Democracy: The Supreme Court as a National Policy-maker, «Journal of Public Law», 6: 279-295.

Dolbeare, Kenneth M.:

1967 Trial Courts in Urban Politics.

EckmofF, Thorstein:

1965 Impartiality, Separation of Powers and Judicial Independence, «Scandinavian Studies in Law», 9.

Ferrajoli, L.:

1973 Per una riforma democrática dell'ordinamento giudiziario, «Problemi del Socialismo», núm. 18 , noviembre-diciembre.

Glick, Henry R.:

1971 Supreme Courts in State Politics; An Investigation of the Judicial Role.

Herndon, James:

1964 The role of the judiciary in State Political Systems, en G. Schubert, editor (1964): 153-161.

JACOB, Herbert, y VinEs, Kenneth N. (eds.):

1965 Politics in the American States: A Comparative Analysis (Boston, Little).

Justicia Democrética:

1978 Los jueces contra la dictadura (justicia y política en el franquismo), Madrid, Túcar Ediciones.

KIRCHHEIMER, Otto:

1961 Political Justice: The Use of Legal Procedure for Political Ends (Princeton University Press). 
KRISLOv, Samuel:

1965 The Supreme Court in the Political Process (New York, Macmillan). Levin, Martin A.:

1972 Urban Politics and Judicial Behavior, «Journal of Legal Studies», 1: 193 y sigs.

MarTíneZ-VARES, Santiago:

1979 Poder judicial y comunidades autónomas. Ponencia presentada a las III Jornadas de Estudios Andaluces. Granada, 29-31 octubre 1979.

Morrison, Fred:

1973 Courts and the Political Process in England.

Murphy, Walter F., y PRITCHETT, C. H. (eds.):

1961 Courts, judges and politics: an introduction to the judicial process (New York, Random House).

MuRPHY, Walter F.:

1962 Congress and the Court: A Case Study in the American Political Process (University of Chicago Press).

Neppi Modona, G.:

1969 Sciopero, potere politico e magistratura, $1870-1922$ (Bari, Laterza).

Peltason, Jack W.:

1955 Federal Courts in the Political Process (Garden City, Doubleday).

PritchetT, C. H.:

1963 (e. o. 1948) The Roosevelt Court: A Study in judicial politics and

Salazar Alonso, Rafael: values, 1937-1947 (New York, Octagon Books).

1930 La justicia bajo la dictadura (Madrid, Zeus).

SCHUBERT, Glendon:

1965 Judicial policy-making: The Political Role of the Courts (Chicago; Scott, Foresman).

SHAPIRO, Martin:

1964 Law and Politics in the Supreme Court (New York, Free Press).

ToHaRIA, José Juan:

1957 Judicial independence in an authoritarian regime: the case of contempo-

ULç, Otto: rary Spain, «L. S. R.», vol. 9, núm. 3, págs. 475-496.

1972 The judge in a communist State: a view from within.

Vines, Kenneth N., y JACOB, Herbert:

1963 Studies in judicial politics (New Orleans, Tulane University Studies in Political Science, núm. 8). 